\title{
EFFECTS OF A PROTEIN-FREE DIET ON AMINO ACIDS AND SEX HORMONES OF RATS DURING THE EARLY POSTIMPLANTATION STAGES OF PREGNANCY
}

\author{
E. KÖHLER, F. WOJNOROWICZ AND K. BORNER* \\ Pharmakologisches Institut der Freien Universität Berlin, and \\ *Institut für Klinische Chemie (Klinikum Steglitz) der Freien Universität, \\ Berlin, West Germany
}

(Received 21st February 1974)

Summary. In rats, the effect of a protein-free diet on the maintenance of gestation was investigated during the early postimplantation stages (Days 7 to 10). The growth kinetics of the implantation site, the concentrations of free amino acids in the implantation sites as well as in the maternal liver and the levels of sex hormones in the maternal serum were determined. The results of these studies showed that in the whole implantation site, the absolute amounts of DNA, RNA and nitrogen were significantly lower in the rats fed a protein-free diet compared to the values for rats fed an optimal protein diet. In rats fed a proteinfree diet, the concentrations of essential amino acids decreased in the whole implantation site to the same extent as in the maternal liver. In the case of the non-essential amino acids, however, a significant increase in the concentrations of some of the amino acids was observed in the maternal liver. With regard to the essential amino acid pool, it appears that the liver and the decidua can be regarded as being in a dynamic equilibrium.

Peripheral prolactin and progesterone concentrations significantly decreased on Day 8 of gestation, while the amounts of $\mathrm{LH}$ and total oestrogens remained unchanged.

\section{INTRODUGTION}

There are many reports in the literature which show that the nutritional state of the pregnant rat is a factor which influences embryonic growth and the differentiation processes (Warkany, 1943, 1944, 1945; Richardson \& Hagan, 1946; Pike, 1951; Nelson \& Evans, 1953; Kalter \& Warkany, 1959; Chow \& Lee, 1964; Niiyama \& Shoji, 1972; Köhler \& Merker, 1973). It was found, for example, that a reduction in the protein of the maternal diet instituted shortly after copulation resulted in embryonic loss, but that the same dietary restrictions applied after the placenta became functional did not hinder the continuation of pregnancy. In most of these rats, the gestation period was 
prolonged and the average weight and size of the offspring were less than those of rats fed a balanced diet.

These results were unexpected in view of the fact that the absolute amino acid requirements of the growing embryo, relative to its weight, are higher during the second half of gestation, and suggest that a protein-free diet influences the early stages of pregnancy indirectly by affecting the function of some controlling or regulating systems. No precise data appear to exist concerning the availability of amino acids to the growing embryo or to the maternal requirements of pregnant rats maintained on a balanced or protein-restricted diet.

In this study, we have investigated the differences in the amino acid availability in the maternal tissues under conditions of normal and protein-free diets between Days 7 and 10 of gestation. In addition, the concentrations of sex hormones in the maternal serum were investigated in control and experimental animals in order to determine the effects of dietary changes.

\section{MATERIALS AND METHODS}

Animals

Virgin albino rats (strain Wistar SW 70, Winkelmann Breeding Company, Borchen, West Germany), 70 days old and weighing $170 \pm 5 \mathrm{~g}$, were used. The animals were kept at $26^{\circ} \mathrm{C}$ and $60 \%$ air humidity in a defined dark/light rhythm (10 hr light) in order to standardize diurnal variations. All animals were maintained under pair-feeding conditions. The daily food intake within a 4-hr period was about $10 \mathrm{~g}$ when the stock diet (Altromin C 1000) was used and did not change when the protein-free $\operatorname{diet}$ (Altromin C 1030) was given. The protein-free diet was prepared by substituting the protein portion with isocaloric amounts of carbohydrates while all other constituents remained constant. To prevent coprophagy, the protein-free fed rats were kept in wirebottomed cages. When not otherwise stated, the protein-free diet was given from Day 0 of gestation (the day on which the females were mated). To obtain maternal and embryonic tissues of known gestational stages, mating took place within a 2-hr period from 08.00 to 10.00 hours. Food was withheld from all rats for $4 \mathrm{hr}$ before autopsy, which took place between 08.00 and 10.00 hours at 24-hr intervals.

\section{Methods}

Concentrations of free amino acids were determined in whole implantation sites and maternal liver tissue. During the early postimplantation stages, the whole implantation site consists predominantly of the decidua. Embryonic cells on Day $8+8 \mathrm{hr}$ represent approximately $0.002 \%$, and on Day $10+8 \mathrm{hr}$ no more than $0.7 \%$ of the whole implantation site (Köhler, Merker, Ehmke \& Wojnorowicz, 1972). As a result of the small number of embryonic cells compared with the maternal tissue in the implantation site, it is not possible to separate the embryonic cells accurately from the decidual tissue in sufficient numbers for analysis. All studies were therefore carried out using whole implantation sites. We assumed that the small number of embryonic cells did 
not notably contribute to the values measured. For each experiment, $100 \mathrm{im}$ plantation sites or $100 \mathrm{mg}$ of the right inferior lobe of the liver of ten pregnant rats were pooled in order to obtain a representative specimen. The tissues were homogenized and extracted with $10 \mathrm{ml}$ of $1 \%(\mathrm{w} / \mathrm{v})$ picric acid/g tissue. After centrifugation, the supernatant was applied to a $1.0 \times 10.0 \mathrm{~cm}$ column of Dowex $1 \times 8$ (200 to 400 mesh). The column was eluted with four 2-ml portions of $0.02 \mathrm{~N}-\mathrm{HCl}$. The combined eluates were freeze dried and the residues were redissolved in an approximate volume of $0.1 \mathrm{~N}-\mathrm{HCl}$ to obtain suitable concentrations for analyses. Quantitative amino acid analysis was carried out on a Technicon amino acid analyser, using a single column procedure with norleucine as the internal standard. A single analysis was performed on each sample, since duplicate analyses by this procedure were found to agree within $2 \%$.

An extraction procedure similar to the one described by Schmidt \& Tannhauser (1945) was used for the estimation of RNA and DNA in whole implantation sites. Acid-insoluble constituents were precipitated with ice-cold perchloric acid at a final concentration of $0.02 \mathrm{~N}$. After washing the precipitate three times with ice-cold $0.02 \mathrm{~N}$-perchloric acid containing pyrophosphate $(0.06 \mathrm{M})$, the RNA was hydrolysed with $0.3 \mathrm{~N}-\mathrm{NaOH}$ for $1 \mathrm{hr}$ at $37^{\circ} \mathrm{C}$. After acidifying with perchloric acid, constituents that were still acid-precipitable were removed by centrifugation. The supernatant was used for the RNA determination using the Orcinol method. The sediment was subsequently washed with cold $0.02 \mathrm{~N}-$ perchloric acid, centrifuged, and the DNA was extracted twice with $2.0 \mathrm{ml}$ $0.5 \mathrm{~N}$-perchloric acid at $75^{\circ} \mathrm{C}$ for $15 \mathrm{~min}$. Since only $90 \%$ of the DNA was recovered in the first extraction, an additional extraction step had to be performed for a quantitative determination of DNA. This determination was carried out according to the method of Burton (1956).

The nitrogen content of the tissues was measured using the Kjeldahl method.

\section{Determination of sex hormones}

Rats were anaesthetized with ether and blood was collected by puncture of the abdominal aorta and was then allowed to clot at $4^{\circ} \mathrm{C}$ for $30 \mathrm{~min}$. Serum was separated by centrifugation and stored at $-20^{\circ} \mathrm{C}$ until it was assayed. For each measurement, the serum of one pregnant animal was used. The concentrations of total oestrogens and progesterone were determined by radioimmunoassay according to the method of Hasan, von Berswordt-Wallrabe \& Neumann (1971).

Prolactin and LH concentrations were determined by radioimmunoassay using the method of Parlow according to the accounts by Greenwood, Hunter \& Glover (1963), Berson, Yalow, Glick \& Roth (1964) and Midgley (1966, 1967).

\section{RESULTS}

Effect of maternal dietary restriction on the survival of the embryo

In order to investigate the effects of maternal dietary protein deficiency on embryonic development during various periods of gestation, the semi-synthetic 
full diet was replaced by a protein-free diet on Day 0, Day 6 or Day 14 of gestation. As can be seen from the data compiled in Text-fig. 1, a 100\% resorption of the embryos was found in rats which were subjected to a protein-free regimen during the whole period of gestation or during the first 10 days of pregnancy. When, however, the protein-free diet was given after implantation was completed (on Day 6 of gestation), only a small increase $(10 \%)$ in the resorption rate was observed compared to the control values. When the proteinfree diet was instituted after the phase of organogenesis, i.e. Days 14 to 20 , the survival of the embryos was not affected at all.

Since nothing is known of the growth rate of the implantation site of rats fed a protein-free diet starting from Day 0 of gestation, the DNA, RNA and nitrogen content was determined during the early postimplantation stages. Although the total concentrations of DNA, RNA and nitrogen per implantation site were much lower in the experimental group, the growth rates of the implantation sites in the control and experimental groups were not greatly different (Text-fig. 2).

Effects of a protein-free diet on the free amino acid concentrations in the decidual tissue and the maternal liver during the early postimplantation stages

Before evaluating the changes in amino acid availability in rats fed a proteinfree diet, the same parameters during pregnancy under normal dietary conditions had to be investigated. Text-figures 3 and 4 demonstrate that all the amino acids studied increased continuously in the decidual tissue during the postimplantation stages. On Day 10, a tenfold or greater increase in the concentration of histidine, methionine, phenylalanine, and tyrosine was found, an increase of approximately tenfold for lysine, valine, leucine, isoleucine, arginine, aspartic acid, alanine, and proline, and a smaller increase for cystine, serine, glycine and glutamic acid. The data compiled in Text-fig. 5 show that in the maternal liver, the concentrations of essential amino acids, calculated per $g$ nitrogen, remained unchanged from Day 7 to Day 10 of gestation, except for a highly significant increase in the concentrations of the basic amino acids (lysine, histidine, and arginine) observed on Day 8 of gestation. Calculations of the ratios of individual amino acids between the decidual tissue and the maternal liver showed a constant ratio for each of the essential amino acids from Day 7 to Day 9 of gestation with the exception of phenylalanine (Table 1). On Day 10, altered ratios for some of the essential amino acids studied were found, resulting in a large increase in amino acid concentrations in the whole implantation site. The ratios of the non-essential amino acids varied between the two groups studied and within this period of gestation (Table 2).

When the concentrations of amino acids in the implantation sites were compared, it was found that they were all lower in the rats fed a protein-free diet. An almost identical picture was obtained for the non-essential amino acids, with the exception of serine and glycine (Text-figs $6 \mathrm{a}$ and $\mathrm{b}$ ). The concentrations of all essential amino acids showed a sharp and significant decrease from Day 7 to Day 8 and remained nearly constant thereafter. Wide variations in the concentrations of some of the non-essential amino acids (proline, cystine) could be observed between Day 7 and Day 10 (Text-fig. 6b). On Day 10 of 


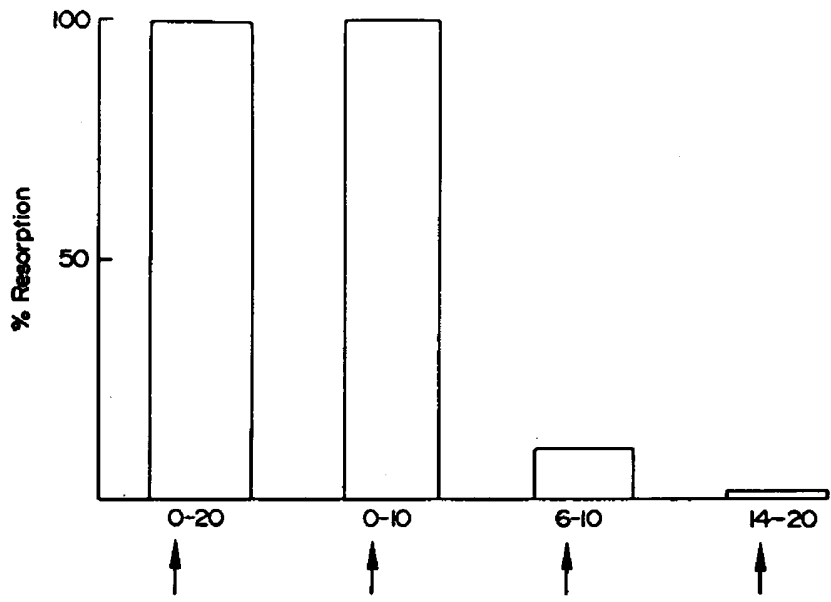

Doy of gestation

TEXT-FIG. 1. Effects of the duration of the maternal dietary protein restriction on embryonic resorption rate in rats. Resorptions were determined on Day 20. In control animals, the resorption amounted to $1.5 \%$. Each value is the mean of 100 embryos for each group. The arrows represent the days on which a protein-free diet was initiated.

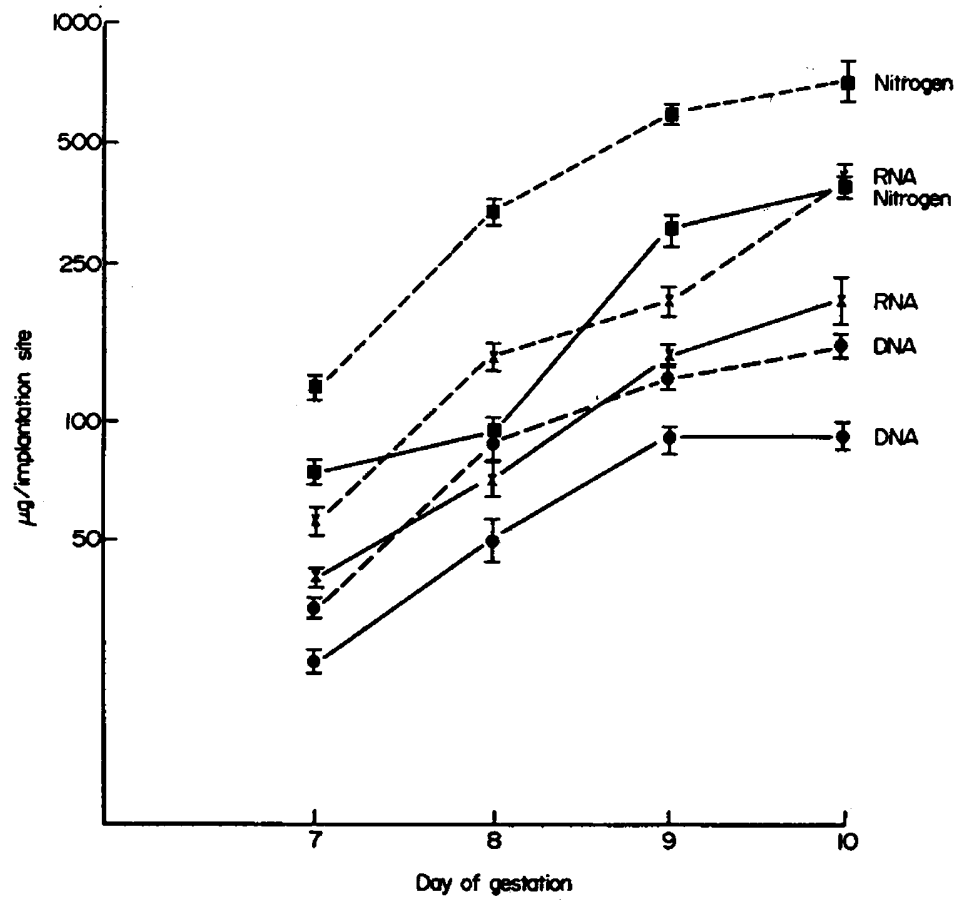

Text-Fig. 2. Effect of maternal dietary protein restriction on the growth kinetics of the implantation site during early postimplantation stages in rats on control $(\longrightarrow)$ and protein-free (--) diets. The protein-free diet was given from Day 0 to Day 10 of gestation. Each point and vertical bar represents the mean \pm S.D. of thirty implantation sites. 
gestation, the concentrations of the essential and non-essential amino acids were about $50 \%$ of the control values with three exceptions: methionine, for which an $80 \%$ decrease was measured, and serine and glycine, for which the values showed little change from the corresponding control values.

When the concentrations of essential amino acids were determined in maternal liver and compared with the values found in the decidual tissue, a similar decrease in concentration was found. A comparison of the ratios of the

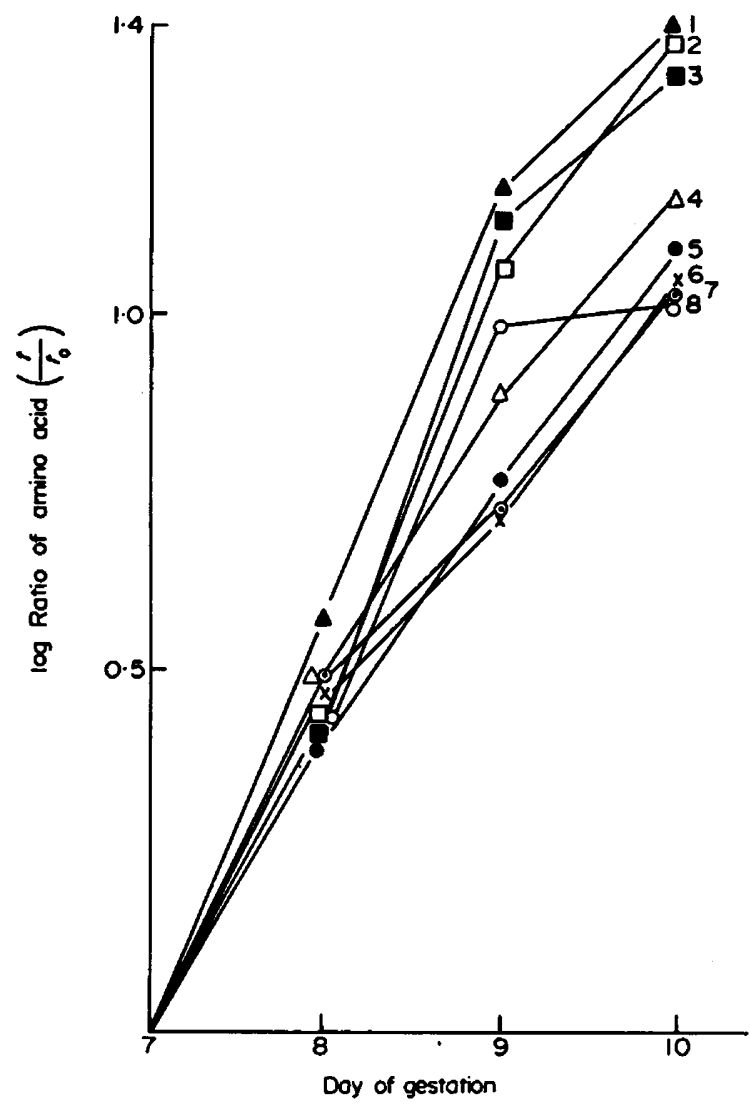

TEXT-FIG. 3. Increase in concentrations of free essential amino acids in the implantation sites of rats fed a balanced diet during the early postimplantation stages. Amino acid concentrations determined on Day 7 of gestation are taken as reference points and set equal to 1.0 . Values of amino acid concentrations measured during later stages of pregnancy are expressed relative to Day 7 and the $\log$ of the ratio is plotted versus the day of gestation. On Day $7\left(t_{0}\right)$ of gestation, the following values were obtained (mean \pm S.D.): $1=$ histidine, $0.40+0.04 \mathrm{nmol}: 2=$ methionine, $0.20+0.02$ nmol; $3=$ phenylalanine, $0.30 \pm 0.03 \mathrm{nmol} ; 4=$ lysine, $1.25 \pm 0.20 \mathrm{nmol} ; 5=$ valine, $1.05 \pm 0.30 \mathrm{nmol}$; $6=$ leucine, $0.80 \pm 0.09 \mathrm{nmol} ; 7=$ isoleucine, $0.45 \pm 0.04 \mathrm{nmol} ; \overline{8}=$ arginine, $0.25 \pm 0.07 \mathrm{nmol}$. The values given represent mean values of three experiments.

individual essential amino acids in the decidual tissue and maternal liver showed identical values in protein-free and fully fed animals (Table 1). In contrast to the decidual tissue, however, where the concentrations of nonessential amino acids decreased according to the duration of the dietary protein 
deficiency, the concentration of some amino acids increased in the maternal liver (Text-fig. 7 and Table 2). The concentrations of some of the non-essential amino acids showed a highly significant increase from Days 9 to 10 of gestation, reaching values which were two to four times those of the corresponding controls.

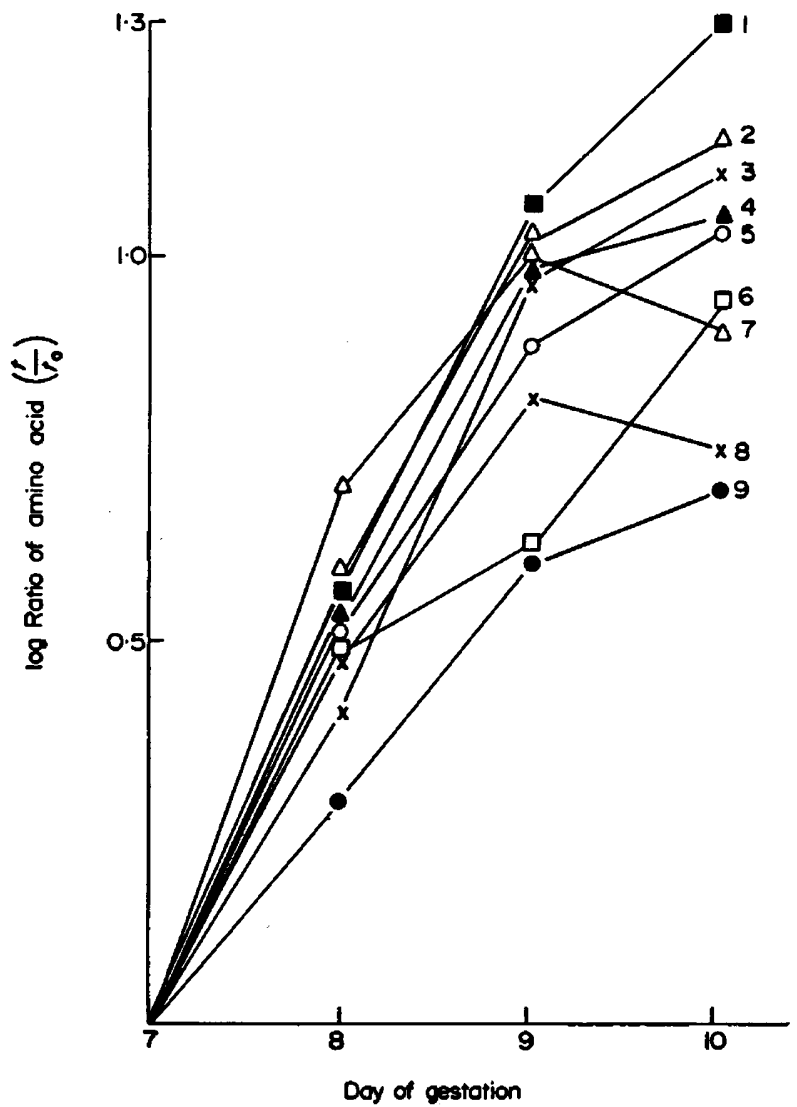

TexT-FIG. 4. Increase in concentrations of free non-essential amino acids in the implantation sites of rats fed a balanced diet during the early postimplantation stages. For details, see legend to Text-fig. 3. On Day $7\left(t_{0}\right)$ of gestation, the following values were obtained (mean \pm S.D.) $: 1=$ tyrosine, $0.30 \pm 0.03 \mathrm{nmol} ; 2=$ ornithine, $0.40 \pm 0.04 \mathrm{nmol}$; $3=$ aspartic acid, $5 \cdot 80 \pm 0 \cdot 10 \mathrm{nmol} ; 4=$ alanine, $8 \cdot 20 \pm 0.80 \mathrm{nmol} ; 5=$ proline, $2 \cdot 60 \pm$ $0.30 \mathrm{nmol} ; 6=$ cystine, $0.70 \pm 0.002 \mathrm{nmol} ; 7=$ serine, $3.50 \pm 0.30 \mathrm{nmol} ; 8=$ glycine, $16.00 \pm 1.00 \mathrm{nmol} ; 9=$ glutamic acid, $26 \cdot 80 \pm 0.30 \mathrm{nmol}$. The values given represent mean values of three experiments.

Effect of a protein-free diet on sex hormone concentrations in maternal serum

The data compiled in Table 3 show that in rats fed a balanced diet, the concentrations of serum progesterone and total oestrogens remained nearly constant except for an increase in progesterone of approximately $20 \%$ from Day 6 to Day 10 of gestation. 


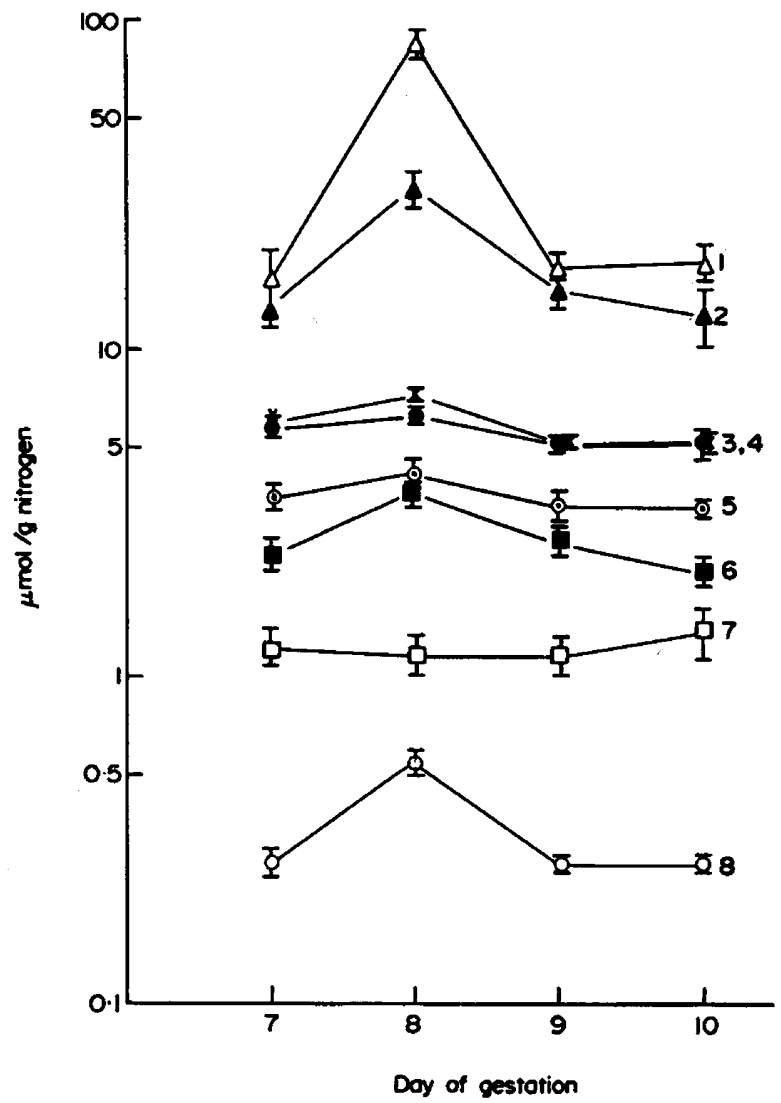

Text-FIG. 5. Concentrations of some free essential amino acids ( $\mu \mathrm{mol} / \mathrm{g}$ nitrogen) in the maternal liver of rats fed a balanced diet during the early postimplantation stages. Each point and vertical bar represents the mean \pm S.D. of three experiments. For further details, see 'Materials and Methods'. $1=$ Lysine; $2=$ histidine; $3=$ leucine; $4=$ valine; $5=$ isoleucine; $6=$ phenylalanine; $7=$ methionine; $8=$ arginine.

Table 1. Ratios of some essential amino acids between the whole implantation site and the maternal liver during early postimplantation stages in rats

\begin{tabular}{|c|c|c|c|c|c|c|c|c|c|}
\hline \multirow{2}{*}{$\begin{array}{l}\text { Day of } \\
\text { gestation }\end{array}$} & \multirow{2}{*}{ Diet } & \multicolumn{8}{|c|}{ Ratios of essential amino acids calculated per $g$ nitrogen } \\
\hline & & Valine & $\begin{array}{l}\text { Methio- } \\
\text { nine }\end{array}$ & $\begin{array}{c}\text { Iso- } \\
\text { leucine }\end{array}$ & Leucine & $\begin{array}{l}\text { Phenyl- } \\
\text { alanine }\end{array}$ & Lysine & Histidine & Arginine \\
\hline 7 & $\begin{array}{l}\text { Stock } \\
\text { Protein- } \\
\text { free }\end{array}$ & $\begin{array}{l}2 \cdot 5 \\
2 \cdot 5\end{array}$ & $\begin{array}{l}2 \cdot 0 \\
2 \cdot 0\end{array}$ & $\begin{array}{l}1 \cdot 7 \\
1 \cdot 7\end{array}$ & $\begin{array}{l}2 \cdot 0 \\
2 \cdot 0\end{array}$ & $\begin{array}{l}1 \cdot 4 \\
1 \cdot 4\end{array}$ & $\begin{array}{l}1 \cdot 5 \\
1 \cdot 5\end{array}$ & $\begin{array}{l}0.7 \\
0.7\end{array}$ & $\begin{array}{l}12 \\
12\end{array}$ \\
\hline 8 & $\begin{array}{l}\text { Stock } \\
\text { Protein- } \\
\text { free }\end{array}$ & $\begin{array}{l}2 \cdot 5 \\
2 \cdot 5\end{array}$ & $\begin{array}{l}2 \cdot 0 \\
2 \cdot 0\end{array}$ & $\begin{array}{l}1 \cdot 7 \\
1 \cdot 7\end{array}$ & $\begin{array}{l}2 \cdot 0 \\
2 \cdot 0\end{array}$ & $\begin{array}{l}1 \cdot 4 \\
1 \cdot 4\end{array}$ & $\begin{array}{l}1 \cdot 5 \\
1 \cdot 5\end{array}$ & $\begin{array}{l}0.7 \\
0.7\end{array}$ & $\begin{array}{l}12 \\
12\end{array}$ \\
\hline 9 & $\begin{array}{l}\text { Stock } \\
\text { Protein- } \\
\text { free }\end{array}$ & $\begin{array}{l}2 \cdot 5 \\
2 \cdot 5\end{array}$ & $\begin{array}{l}2 \cdot 0 \\
2 \cdot 0\end{array}$ & $\begin{array}{l}1 \cdot 7 \\
1 \cdot 7\end{array}$ & $\begin{array}{l}2 \cdot 0 \\
2 \cdot 0\end{array}$ & $\begin{array}{l}3 \cdot 5 \\
3 \cdot 5\end{array}$ & $\begin{array}{l}1 \cdot 5 \\
1.5\end{array}$ & $\begin{array}{l}0.7 \\
0.7\end{array}$ & $\begin{array}{l}12 \\
12\end{array}$ \\
\hline 10 & $\begin{array}{l}\text { Stock } \\
\text { Protein- } \\
\text { free }\end{array}$ & $\begin{array}{l}3 \cdot 3 \\
3 \cdot 3\end{array}$ & $\begin{array}{l}4 \cdot 2 \\
4 \cdot 2\end{array}$ & $\begin{array}{l}2 \cdot 0 \\
2 \cdot 0\end{array}$ & $\begin{array}{l}2 \cdot 3 \\
2 \cdot 3\end{array}$ & $\begin{array}{l}4 \cdot 5 \\
4 \cdot 5\end{array}$ & $\begin{array}{l}1 \cdot 6 \\
1 \cdot 6\end{array}$ & $\begin{array}{l}1 \cdot 1 \\
1 \cdot 1\end{array}$ & $\begin{array}{l}12 \\
12\end{array}$ \\
\hline
\end{tabular}

The ratio values given are those of the amino acid concentrations in the implantation sites compared with those in the maternal liver expressed as unity. 
When rats were fed a protein-free diet from Day 0 of gestation, a decrease in the progesterone to levels which were approximately $50 \%$ lower than in the control group could be measured on Day 8. The values found for the total oestrogens remained unchanged. No difference was recorded in the serum concentration of $\mathrm{LH}$ in the rats fed the balanced $(7 \cdot 0 \pm 1 \cdot 0 \mu \mathrm{g} / 100 \mathrm{ml}, \mathcal{N}=8)$

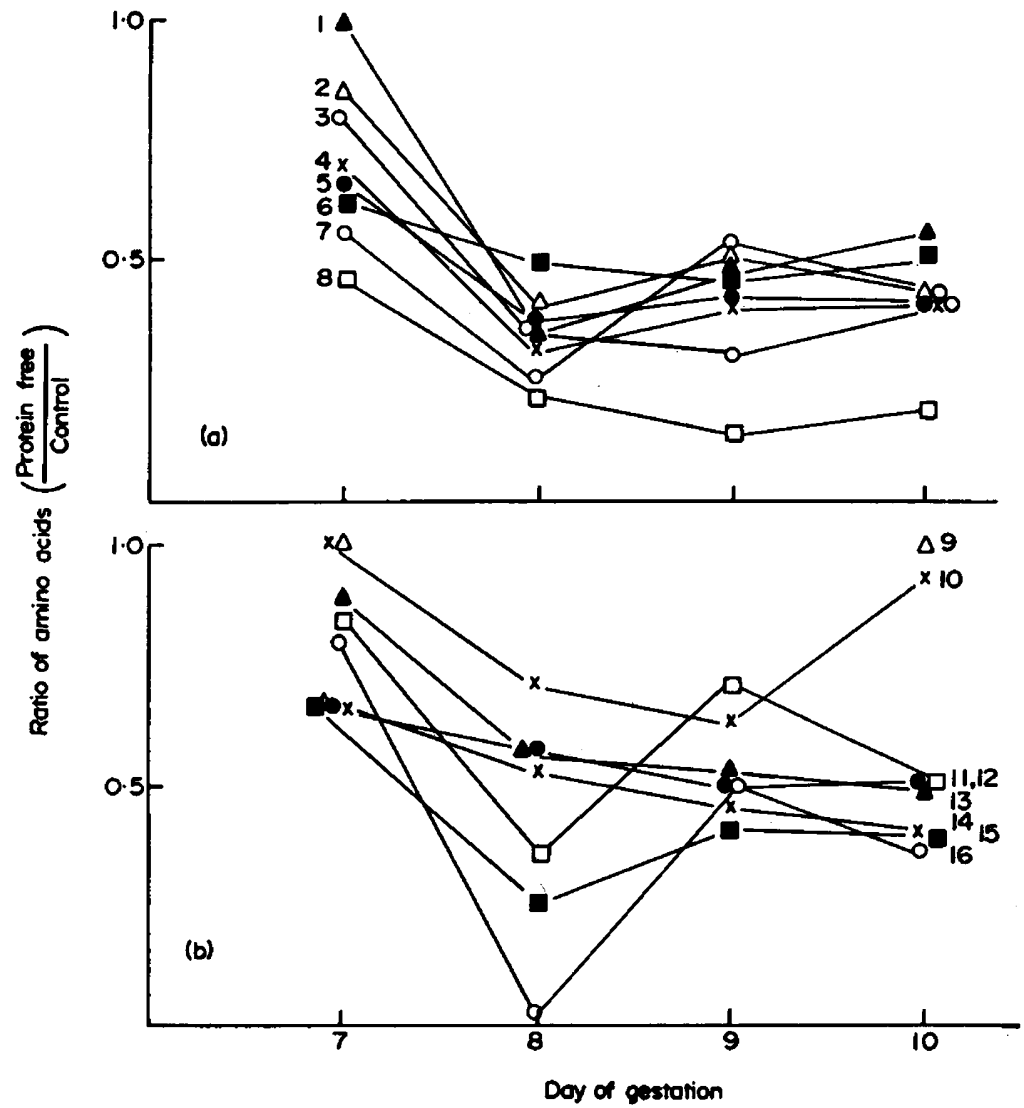

TeXT-FIG. 6. Effect of maternal dietary protein restriction on the concentrations of some free (a) essential, and (b) non-essential amino acids in the whole implantation site in rats. The ratio indicates the quotient of amino acid concentrations (nmol/implantation site) of implantation sites of rats fed a protein-free or a stock diet. The protein-free diet was given from Day 0 to Day 10 of gestation and the animals were killed at 24-hr intervals starting on Day 7 of gestation. For further details, see 'Materials and Methods'. 1 = Histidine; $2=$ lysine; $3=$ arginine; $4=$ leucine $5=$ valine; $6=$ phenylalanine; $7=$ isoleucine; $8=$ methionine; $9=$ serine (this amino acid could be separated accurately from threonine only on Days 7 and 10 of gestation); $10=$ glycine; 11 = glutamic acid; $12=$ cystine; $13=$ alanine; $14=$ aspartic acid; $15=$ tyrosine; $16=$ proline.

or protein-free $(6.9 \pm 0.8 \mu \mathrm{g} / 100 \mathrm{ml}, \mathcal{N}=8)$ diet, but a significant decrease $(P<0.001)$ in the concentration of prolactin was measured in the rats fed the protein-free diet $(1.9 \pm 0.2 \mu \mathrm{g} / 100 \mathrm{ml}, \mathcal{N}=8)$ compared to that in the rats fed the balanced diet $(3 \cdot 3 \pm 0.5 \mu \mathrm{g} / 100 \mathrm{ml}, \mathcal{N}=8)$. 
Table 2. Ratios of some non-essential amino acids between the decidual tissue and the maternal liver during early postimplantation stages in rats

\begin{tabular}{|c|c|c|c|c|c|c|c|c|c|}
\hline \multirow{2}{*}{$\begin{array}{l}\text { Day of } \\
\text { gestation }\end{array}$} & \multirow{2}{*}{ Diet } & \multicolumn{8}{|c|}{ Ratios of non-essential amino acids calculated per $g$ nitrogen } \\
\hline & & $\underset{\text { acid }}{\text { Aspartic }}$ & Serine & $\begin{array}{c}\text { Glutamic } \\
\text { acid }\end{array}$ & Proline & Glycine & Alanine & Cystine & Tyrosine \\
\hline 7 & $\begin{array}{c}\text { Stock } \\
\text { Protein- } \\
\text { free }\end{array}$ & $\begin{array}{l}3 \cdot 8 \\
1 \cdot 3\end{array}$ & $\begin{array}{l}2 \cdot 2 \\
1 \cdot 4\end{array}$ & $\begin{array}{r}10 \cdot 5 \\
5 \cdot 7\end{array}$ & $\begin{array}{r}9 \cdot 0 \\
10 \cdot 0\end{array}$ & $\begin{array}{l}3 \cdot 5 \\
3 \cdot 6\end{array}$ & $\begin{array}{l}2 \cdot 0 \\
3 \cdot 8\end{array}$ & $\frac{3.5}{-t}$ & $\begin{array}{l}2 \cdot 3 \\
2 \cdot 2\end{array}$ \\
\hline 8 & $\begin{array}{l}\text { Stock } \\
\text { Protein- } \\
\text { free }\end{array}$ & $\begin{array}{l}3.8 \\
1.0\end{array}$ & $\frac{2 \cdot 2}{-*}$ & $\begin{array}{l}5.7 \\
4 \cdot 7\end{array}$ & $\begin{array}{l}15.0 \\
10.0\end{array}$ & $\begin{array}{l}4 \cdot 0 \\
3 \cdot 4\end{array}$ & $\begin{array}{l}2 \cdot 8 \\
2 \cdot 0\end{array}$ & $3 \cdot 1$ & $\begin{array}{l}2 \cdot 4 \\
2 \cdot 0\end{array}$ \\
\hline 9 & $\begin{array}{l}\text { Stock } \\
\text { Protein- } \\
\text { free }\end{array}$ & $\begin{array}{l}4.6 \\
1.6\end{array}$ & 3.6 & $\begin{array}{l}5 \cdot 5 \\
4 \cdot 2\end{array}$ & $\begin{array}{r}8 \cdot 0 \\
12 \cdot 9\end{array}$ & $\begin{array}{l}4 \cdot 2 \\
3 \cdot 2\end{array}$ & $\begin{array}{l}3 \cdot 8 \\
2 \cdot 3\end{array}$ & $\frac{1 \cdot 2}{-}+$ & $\begin{array}{l}5 \cdot 3 \\
4 \cdot 2\end{array}$ \\
\hline 10 & $\begin{array}{l}\text { Stock } \\
\text { Protein- } \\
\text { free }\end{array}$ & $\begin{array}{l}5 \cdot 4 \\
1 \cdot 1\end{array}$ & $\begin{array}{l}1.5 \\
1 \cdot 4\end{array}$ & $\begin{array}{l}5 \cdot 0 \\
2 \cdot 6\end{array}$ & $\begin{array}{r}11.0 \\
7.5\end{array}$ & $\begin{array}{l}2 \cdot 3 \\
2 \cdot 3\end{array}$ & $\begin{array}{l}2.0 \\
1.7\end{array}$ & $\stackrel{4 \cdot 6}{-\dagger}$ & $\begin{array}{l}5 \cdot 4 \\
4 \cdot 2\end{array}$ \\
\hline
\end{tabular}

The ratios given are those of the amino acid concentrations in implantation sites compared with those in maternal liver expressed as unity.

* With the procedure employed, an exact separation of serine and threonine was not achieved in the maternal liver and decidual tissue of rats fed the protein-free diet.

$\uparrow$ The amount of cystine was too low in liver tissue to be calculated accurately.

Table 3. Effect of protein-free diet on maternal serum concentrations of progesterone and total oestrogens during early implantation stages in rats

\begin{tabular}{|c|c|c|c|}
\hline \multirow{2}{*}{$\begin{array}{c}\text { Day of } \\
\text { gestation }\end{array}$} & \multirow[t]{2}{*}{ Diet } & \multicolumn{2}{|c|}{$\begin{array}{c}\text { Serum concentration } \\
(\mu \mathrm{g} / 100 \mathrm{ml})\end{array}$} \\
\hline & & Progesterone & Total oestrogens \\
\hline 6 & $\begin{array}{c}\text { Stock } \\
\text { Protein-free }\end{array}$ & $\begin{array}{l}7 \cdot 6 \pm 0 \cdot 13(10) \\
7 \cdot 6 \pm 0.6(10)\end{array}$ & $\begin{array}{l}0.28 \pm 0.02(5) \\
0.28 \pm 0.02(5)\end{array}$ \\
\hline 7 & $\begin{array}{c}\text { Stock } \\
\text { Protein-free }\end{array}$ & $\begin{array}{l}8 \cdot 5 \pm 1 \cdot 0(10) \\
8 \cdot 5 \pm 1 \cdot 0(10)\end{array}$ & $\begin{array}{l}0.27 \pm 0.02(5) \\
0.27 \pm 0.02(5)\end{array}$ \\
\hline 8 & $\begin{array}{c}\text { Stock } \\
\text { Protein-free }\end{array}$ & $\begin{array}{l}9.2 \pm 1.0(33) \\
4.8 \pm 0.8(32)\end{array}$ & $\begin{array}{l}0.27 \pm 0.03(11) \\
0.27 \pm 0.02(7)\end{array}$ \\
\hline 9 & $\begin{array}{c}\text { Stock } \\
\text { Protein-free }\end{array}$ & $\begin{array}{l}9 \cdot 2 \pm 1 \cdot 0(6) \\
4 \cdot 7 \pm 0 \cdot 4(6)\end{array}$ & $\begin{array}{l}0.27 \pm 0.02(5) \\
0.27 \pm 0.03(5)\end{array}$ \\
\hline 10 & $\begin{array}{c}\text { Stock } \\
\text { Protein-free }\end{array}$ & $\begin{array}{l}9.2 \pm 0.6(5) \\
3.8 \pm 0.4(6)\end{array}$ & $\begin{array}{l}0.27 \pm 0.03(5) \\
0.27 \pm 0.03(5)\end{array}$ \\
\hline
\end{tabular}

Values expressed as Mean \pm S.D. Numbers in parentheses indicate the numbers of experiments. 


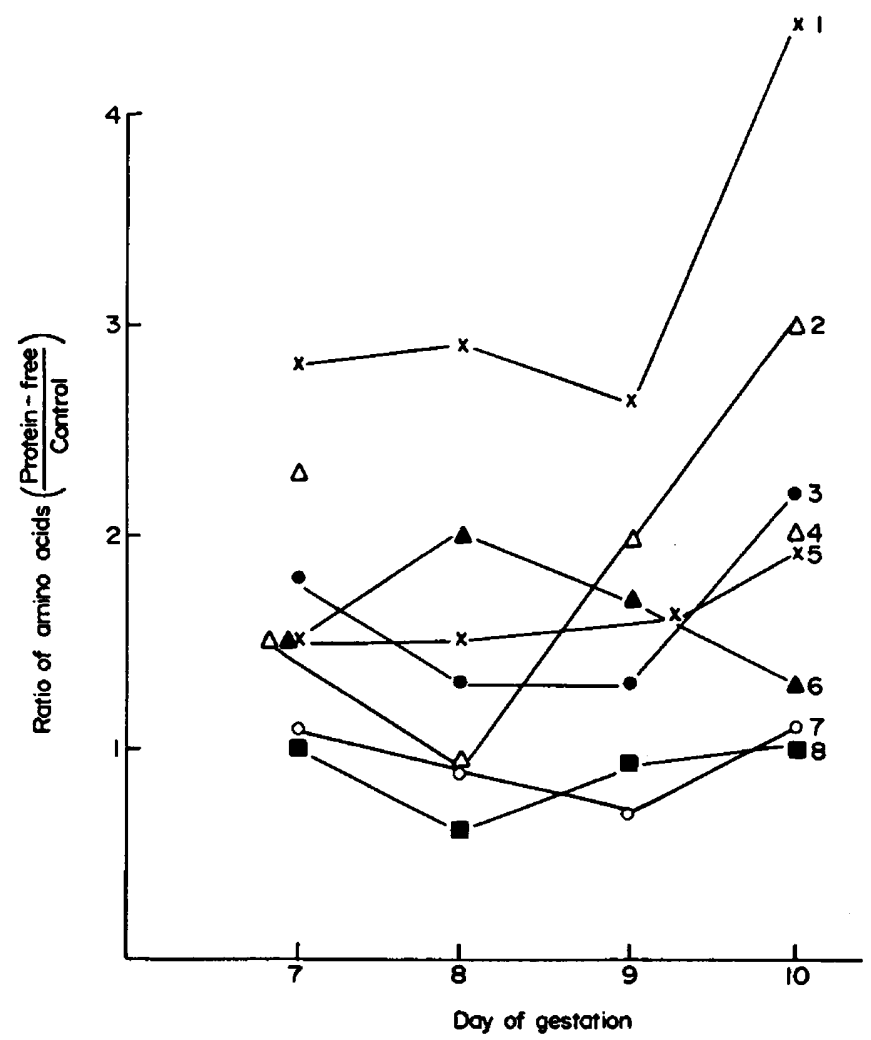

Text-Fic. 7. Concentrations of some free non-essential amino acids in the maternal liver of rats fed a protein-free diet during the early postimplantation stages. The ratio indicates the quotient of amino-acid concentrations ( $\mu \mathrm{mol} / \mathrm{g}$ nitrogen) of the maternal liver of rats fed a protein-free or stock diet. The protein-free diet was given from Day 0 to Day 10 of gestation and the animals were killed at 24-hr intervals starting on Day 7 of gestation. For further details, see 'Materials and Methods'. $1=$ Aspartic acid; 2 = ornithine; $3=$ glutamic acid; $4=$ serine (this amino acid could be separated accurately from threonine only on Days 7 and 10 of gestation); $5=$ glycine; $6=$ alanine; $7=$ proline; $8=$ tyrosine.

\section{DISGUSSION}

The data presented in this paper confirm the findings of Nelson \& Evans (1953) that rats fed a protein-free semi-synthetic diet before implantation fail to maintain pregnancy. If, however, the maternal protein-free diet is instituted after implantation (Day 6 of gestation), the resorption rate only amounts to $10 \%$ of that of normal rats (Text-fig. 1). Closer analysis of the changes that occur in the implantation sites of rats fed a protein-free diet shows a significant growth retardation $(P<0.001$, Text-fig. 2$)$. This is in agreement with the measurements of small amounts of total free amino acids. When the proteinfree diet was instituted on Day 0 of gestation, there was a notable decrease in the amino acid concentration between Day 7 and Day 8 and the level then remained almost unchanged until Day 10 . These findings might be explained on the basis of competition by other maternal tissues for amino acids during this period or by a lower mobilization of amino acids from maternal tissues. 
It seemed, therefore, important to establish the relationship between the free amino acid concentrations in the decidual tissue and the maternal liver in rats fed a protein-free or a normal diet since much evidence points to the liver as a key organ in the regulation of amino acid supply to other organ systems. Regardless of the nutritional condition of the animals, identical ratios were found from Day 7 to Day 10 of gestation for each of the essential amino acids studied (Table 1), while the ratios of the non-essential amino acids showed great variations during this period (Table 2). These results suggest that the essential amino acid pool in the maternal liver can be considered to be in a state of a dynamic equilibrium with that of the decidual tissue, functioning even under the conditions of maternal dietary protein restriction.

Since the deleterious effects on the embryo of maternal dietary protein restriction during the first half of gestation can be overcome by injecting pituitary gonadotrophins (Kinzey \& Screbnik, 1963; Callard \& Leathem, 1970) or sex steroids (Nelson \& Evans, 1954; Hazelwood \& Nelson, 1965; Kinzey, Sands \& Bonds, 1970; Köhler, Wojnorowicz \& Borner, 1975), it seems probable that there was a deficiency of sex hormones under the experimental conditions of the present study, and, in fact, our data demonstrate a decrease in the concentration of prolactin and progesterone on Day 8 of gestation. Thus, a relationship between the decrease in the amino acid concentrations in the tissues studied and the decrease of prolactin and progesterone cannot be ruled out. It is suggested, therefore, that a correlation exists between disturbance of the sex hormone balance and the ability to mobilize amino acids from maternal tissues. In addition, it might be concluded that an adequate amino acid supply is a necessary requirement for maintaining the desired levels of prolactin in the maternal serum and that the effects of protein deficiency on embryonic survival rate are mediated through its effects on hormonal biosynthesis or secretion processes. We do not yet know, however, how dietary protein deficiency causes the inhibition of the synthesis and/or release of the pituitary luteotrophic hormone or through which mechanism this effect exerts its influence.

The fact that, as soon as the placenta is functioning as an endocrine gland, pregnancy will be maintained and viable litters will be born despite dietary restriction indicates that the mechanism of synthesis and/or release of the placental luteotrophic hormone compared with that of the pituitary gland is not affected by dietary protein restriction.

\section{ACKNOWLEDGMENTS}

We are indebted to Dr S. H. Hasan and Mr E. Friedreich of the Schering AG, Berlin, for the measurement of prolactin and LH. This work was supported by grants from the Deutsche Forschungsgemeinschaft given to the Sonderforschungsbereich 29, "Embryonale Entwicklung und Differenzierung (Embryonalpharmakologie)".

\section{REFERENCES}

Berson, S. A., Yalow, R. S., Glick, S. M. \& Roth, J. (1964) Immunoassay of protein and peptide hormones. Metabolism, 13, 1135-1153. 
Burton, K. (1956) A study of the conditions and mechanisms of the diphenylamino reaction for the colorimetric estimation of deoxyribonucleic acid. Biochem. 7. 62, 315-323.

Callard, I. P. \& Leathem, J. H. (1970) Pregnancy maintenance in protein deficient rats. Acta endocr., Copenh. 63, 539-544.

Chow, B. \& LeE, C. J. (1964) Effect of dietary restriction of pregnant rats on body weight gain of the offspring. 7. Nutr. 82, 10-18.

Greenwood, F. C., Hunter, W. M. \& Glover, J. S. (1963) The preparation of $\mathrm{I}^{131}$-labelled human growth hormone of high specific radioactivity. Biochem. $7.89,114-123$.

Hasan, S. H., von Berswordt-Wallrabe, R. \& Neumann, F. (1971) A short review on solid phase radioimmunoassay of steroids. Hormone metab. Res., Suppl. 3, 113-114.

Hazelwood, R. L. \& Nelson, M. M. (1965) Steroid maintenance of pregnancy in rats in the absence of dietary protein. Endocrinology, 77, 999-1013.

KaIter, H. \& WARKaNY, J. (1959) Experimental production of congenital malformations in mammals by metabolic procedure. Physiol. Rev. 39, 69-115.

Kinzey, W. G., SANDs, L. \& Bonds, P. (1970) Maintenance of pregnancy in absence of dietary protein with progesterone. Proc. Soc. exp. Biol. Med. 134, 72-77.

Kinzey, W. G. \& Screbnik, H. H. (1963) Maintenance of pregnancy in protein-deficient rats with short-term injections of ovarian hormones. Proc. Soc. exp. Biol. Med. 114, 158-160.

Köhler, E. \& Merker, H.-J. (1973) Effect of protein-free diet on the survival rate and growth kinetics of rat embryos during different phases of development. Teratology, 8, 225-226.

Köhler, E., Merker, H.-J., Ehmke, W. \& Wojnorowicz, F. (1972) Growth kinetics of mammalian embryos during the stage of differentiation. Naunyn-Schmiedebergs Arch. exp. Path. Pharmak. 272, 169-181.

KöHLER, E., Wojnorowicz, F. \& Borner, K. (1975) The maintenance of pregnancy by progesterone and estrone in rats fed a protein-free diet. Adv. Biosci. (in press).

Midgley, A. R., JR (1966) Radioimmunoassay: a method for human chorionic gonadotrophin and human luteinizing hormone. Endocrinology, 79, 10-18.

Mmgley, A. R., JR (1967) Radioimmunoassay for human follicle-stimulating hormone. 7. clin. Endocr. Metab. 27, 295-299.

Nelson, M. M. \& Evans, H. M. (1953) Relation of dietary-protein levels to reproduction in the rat. 7. Nutr. 51, 71-84.

Nelson, M. M. \& Evans, H. M. (1954) Maintenance of pregnancy in the absence of dietary protein with estrone and progesterone. Endocrinology, 55, 543-549.

Niryama, Y. \& Shoji, C. (1972) Effect of food restriction and ovarian steroids on maintenance of pregnancy in rats. Eigyo To Shokuryo, $25(9), 697-701$.

Prke, R. L. (1951) Congenital cataract in albino rats fed different amounts of tryptophan and niacin. 7. Nutr. 44, 191-204.

Richaroson, L. R. \& Hagan, A. G. (1946) Diet of mother and hydrocephalus in infant rats. J. Nutr. 32, 459-465.

Schmid, D. \& Tannhauser, S. J. (1945) A method for the determination of deoxyribonucleic acid, ribonucleic acid and phosphoproteins in animal tissues. 7. biol. Chem. 161, 83-89.

WARKanY, J. (1943) Effect of maternal rachitogenic diet on skeletal development of young rats. Am. 7 . Dis. Child. 66, 511-516.

WARKaNY, J. (1944) Congenital malformations induced by maternal nutritional deficiency. J. Pediat. $25,476-486$.

Warkany, J. (1945) Manifestations of prenatal nutrition deficiency. Vitams Horm. 3, 73-102. 